\title{
Reproduction Period of Mimagoniates microlepis, from an Atlantic Forest Stream in Southern Brazil
}

\author{
Marcelo Rennó Braga ${ }^{1}$, José Marcelo Rocha Aranha ${ }^{2 *}$ and Jean Ricardo Vitule ${ }^{3}$ \\ Departamento de Zoologia; Universidade Federal do Paraná; C.P. 19020; 81531-990; Curitiba - PR - Brasil
}

\begin{abstract}
Mimagoniates microlepis was collected between January and December/2002. Three sample points were chosen at higher, medium and lower portions of Ribeirão river, located at the east of Paraná state. The reproduction period was observed by the frequency of gonad developmental stages, variation of the gonosomatic relation (RGS) and gonad condition $(K)$. The average length at the first sexual maturity $\left(L_{50}\right)$ and the average length when $100 \%$ of individuals were adults $\left(L_{100}\right)$ were calculated. The intensity of the reproductive activity $(I A R)$ was estimated at each sample point. The reproduction period started in the winter and ended at the end of spring. The high values of IAR encountered demonstrated that the reproductive activity occurred in the whole study area, mainly at the middle portion of the river. Apparently $\mathrm{M}$. microlepis synchronize its fecundation and spawning with the rain regimes using the most suitable times for the cospecific encounters and offspring survival.
\end{abstract}

Key-words: Coastal stream, Blue tetra, East basin

\section{INTRODUCTION}

The coastal streams are often considered as unstable environments (Amaral et al., 1998; Castro, 1999). Fast changes in the water level occur mainly during the summer, causing physical changes in the environment and dragging the fishes, among others creatures downstream. The changeable ambient conditions of these streams must have a decisive role in the selection of flexible characteristics of the fishes such as the reproductive period, age of the first maturation, longevity and growth (Amaral et al., 1999). Among the species of fishes that inhabit the Atlantic Forest is the blue-tetra, Mimagoniates microlepis, which belongs to the Characidae family and Glandulocaudinae subfamily. The presence of glandular tissue and modified scales at the caudal fin of the males,

\footnotetext{
* Author for correspondence
}

among others characteristics, were used as a specific characteristic of the subfamily Glandulocaudinae (Menezes, 1992), but a study of Weitzman et al. (2005) found the evidence that the scales and fin rays of the caudal organ of the males of the tribe Glandulocaudini were not homologous with that of other tribes of Glandulocaudinae. As proposed by

Weitzman et al. (2005) the members of the tribe Glandulocaudini should be recognized as the subfamily Glandulocaudinae and the remaining tribes of the former Glandulocaudinae included in the subfamily Stevardiinae.

$M$. microlepis is an inseminating species; the female is inseminated by the male and retains live sperm cells in her ovary. There is no evidence of the oocytes fertilization in the ovaries (Burns et al., 1995). M. microlepis presents a small size. The males are bigger than the females and reach around 6.5 centimeters. According to Mazzoni and Iglesias-Rios (2002) 
its behavior is diurnal, preferring shallow waters with medium to slow water velocity. Its geographic distribution encloses clear water coastal streams of the eastern Brazil, extending from south the of Bahia to the northeast of Rio Grande do Sul, being also found in some areas of the high Iguaçu river (Weitzman et al.1988). Despite being a relatively abundant fish in the littoral rivers, few studies had been directed to $M$. microlepis. The insemination, testis and sperm morphology of Glandulocaudinae fishes, including $M$. microlepis had been analyzed by Burns et al. (1995). Mazzoni and Iglesias-Rios (2002) studied the longitudinal distribution of $M$. microlepis at Rio de Janeiro, concluding that its occurrence seemed to be correlated with the presence of the vegetal covering. Lampert et al. (2003) studied the feeding habit of $M$. microlepis at Rio Grande do Sul, observing a diet consisting basically of allochtone arthropods, mainly insects, corroborating the results of Sabino and Castro (1990) and Aranha (2000) in the littoral rivers of São Paulo and Paraná, respectively. Through the studies of the reproduction one can understand the mechanisms that involve the perpetuation and modification of species. It also contributes for the understanding of the use that the fishes make of an area, allowing the planning of conservation actions (Hartz et al., 1997; Dias et al., 1998). The present work had its objective to analyze some reproductive tactics of M. microlepis in a littoral river of Paraná State.

\section{MATERIAL AND METHODS}

The study was conducted at the Ribeirão river which belonged to the sub-basin of the Paranaguá bay in the Atlantic basin (Maack, 1981). This river starts at the Prata mountain ridge in the National Park Saint-Hilaire/Hugo Lange, at an altitude of 766 meters above sea level and has its mouth at the Paranaguá bay (Takeuti et al., 1999). According to the classification of Köeppen (1948), the climate in the region is tropical, super humid, without a dry season and frosts. The rains are well distributed during the year, being June and July the driest months and January and February the rainiest. Annually the pluviometric levels are superior to $1000 \mathrm{~mm}$ (Fig. 1) and the average annual air temperature varies from 17 to $21^{\circ} \mathrm{C}$ (Maack, 1981; Simepar, 2005).

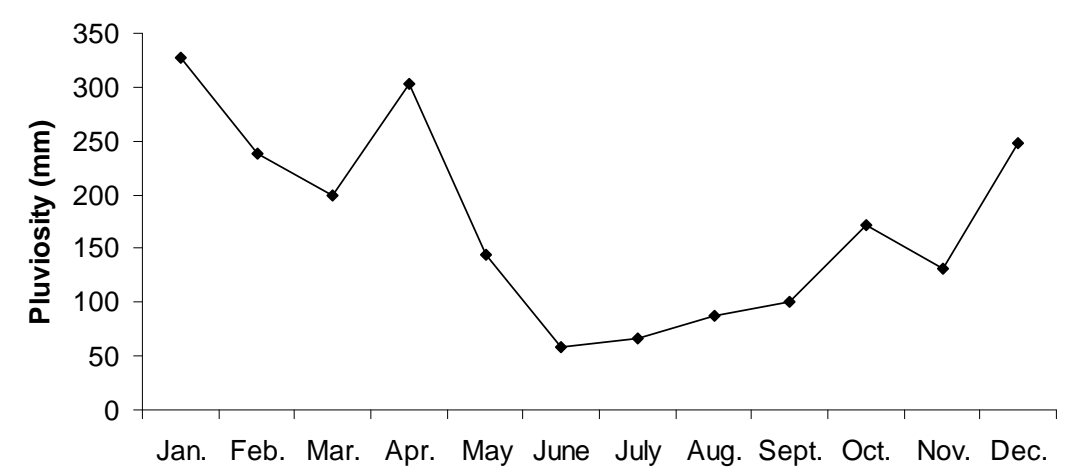

Figure 1 - Month pluviosity at east of Paraná state during 2002 (Simepar, 2005)

Three samples points were chosen, P1 at an upper section of Ribeirão river basin $\left(25^{\circ} 35^{\prime} 17^{\prime \prime} \mathrm{S}\right.$; $\left.48^{\circ} 38^{\prime} 01^{\prime \prime} \mathrm{W}\right), \mathrm{P} 2$ at a middle section $\left(25^{\circ} 36^{\prime} 02^{\prime \prime}\right.$; $\left.48^{\circ} 37^{\prime} 19^{\prime \prime} \mathrm{W}\right)$ and $\mathrm{P} 3$ at a lower section of the river $\left(25^{\circ} 35^{\prime} 21^{\prime \prime} \mathrm{S} ; 48^{\circ} 36^{\prime} 40^{\prime \prime} \mathrm{W}\right)$. During the rainy period the flash floods provoked the rises of the water level, modifications of the physical habitat and an increase of the turbidity and water velocity.

The specimens were collected monthly from January through December of 2002, using the sieves and small trawl nets $(1.30 \times 1.40 \mathrm{~m}$ with $2 \mathrm{~mm}$ mesh). The fishes were measured, weighed and the sex and stage of the gonad activity were identified according to methodology described by Vazzoler (1996). The reproductive period was observed by the variation of the gonosomatic relation (Vazzoler, 1996):

$$
R G S=W o / W t \times 100
$$


(Wo=gonad weight Wt=total weight $)$

and gonad condition (Isaac-Nahum and Vazzoler, 1983):

$$
\begin{gathered}
K=W t / L t^{b}-W c / L t^{b} \\
(W t=\text { total weight; } L t=\text { total length } ; W c=W t-W o ; \\
b=\text { angular coefficient of } W t / L t)
\end{gathered}
$$

The frequency of the individuals in the mature gonad development stage. The average length at the first sexual maturity $\left(\mathrm{L}_{50}\right)$ and the average length when $100 \%$ of individuals were adults $\left(\mathrm{L}_{100}\right)$ were calculated accordingly to Vazzoler (1981). The intensity of the reproductive activity (IAR) was estimated at each sample point as proposed by Agostinho et al. (1993), using the formula as below:

$$
I A R=\frac{\ln N_{i}\left(\frac{n_{i}}{\sum n_{i}}+\frac{n_{i}}{N_{i}}\right) \frac{R G S_{i}}{R G S_{e}}}{\ln N_{m}\left(\frac{n_{i}}{\sum n_{i}}+1\right)} \times 100
$$

$\mathrm{Ni}$, corresponded to the number of the individuals in the sample unit; ni was the number of the mature individuals at the sample unit; $\mathrm{Nm}$ was the number of individuals at the biggest sample unit; $\mathrm{nm}$ was the number of the mature individuals at the biggest sample unit; RGSi was the average gonosomatic relation at the sample unit; RGSe was the largest individual value of the gonosomatic relation.

\section{RESULTS}

A total of 550 specimens of M. microlepis were dissected for the analysis, 262 were females and 288 were males. At sample point 1, 160 individuals were captured, 70 exemplars were females and 90 were males. At sample point 2, 207 individuals were captured, 115 were females and 92 were males. At sample point 3, 183 specimens were captured, 104 were females and 79 were males. The smallest individual captured had 1.5 $\mathrm{cm}$ but its sex could not be determined. The size of the females varied from 2.3 to $5.4 \mathrm{~cm}$ and the size of the males varied from 2.3 to $7.0 \mathrm{~cm}$. The females presented the largest values of average RGS in August (RGS=10.81), September $(\mathrm{RGS}=20.86)$ and October $(\mathrm{RGS}=16.32)$. For the males the largest were observed in July (RGS=3.87), August (RGS=3.31) and September (RGS=3.44) (Fig. 2). The largest average values of the gonad condition for the females were obtained in August ( $\mathrm{K}=9.62 \mathrm{E}-04)$, September $(\mathrm{K}=1.62 \mathrm{E}-03)$ and October $(\mathrm{K}=1.16 \mathrm{E}-03)$ and for the males in July (K=3.52E-04), August $(\mathrm{K}=3.61 \mathrm{E}-04)$ and September (K=3.31E-04) (Fig. 3). The analysis of the frequency of the gonad developmental stages demonstrated the largest frequency of the mature females in September and October and males in July and August (Fig. 4). The frequency of the higher immature females and males was in January. The average length at the first maturation $\left(\mathrm{L}_{50}\right)$ for the females was in a length class of 2.5 $3.0 \mathrm{~cm}$ and the $\mathrm{L}_{100}$ was in a length class of 4.0 $4.5 \mathrm{~cm}$. The $\mathrm{L}_{50}$ for the males was established inside a length class of $3.0+3.5 \mathrm{~cm}$ and the $\mathrm{L}_{100}$ inside a length class of $4.0 \vdash 4.5 \mathrm{~cm}$.

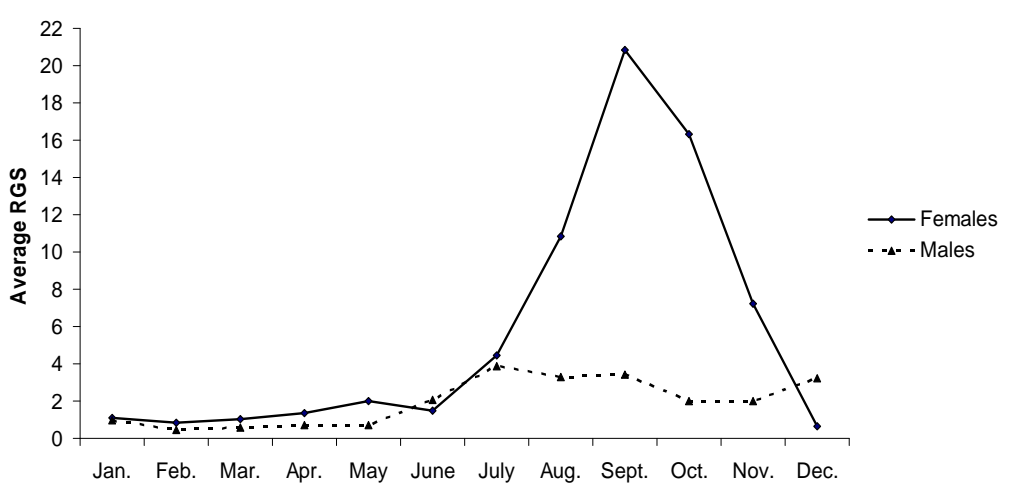

Figure 2 -Average RGS of M.microlepis at Ribeirão River during 2002 


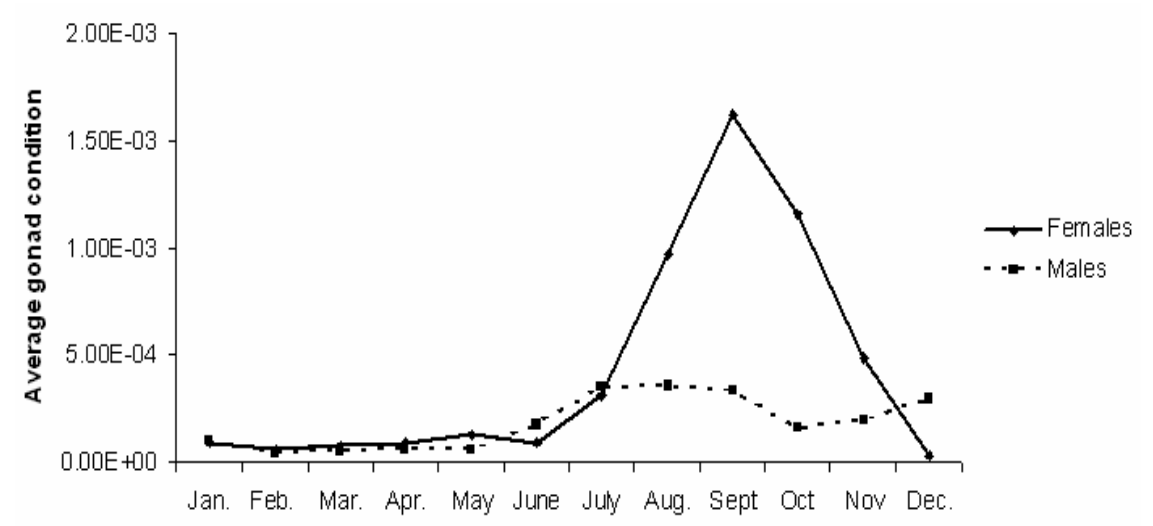

Figure 3 -Average gonad condition of M. microlepis at Ribeirão River during 2002
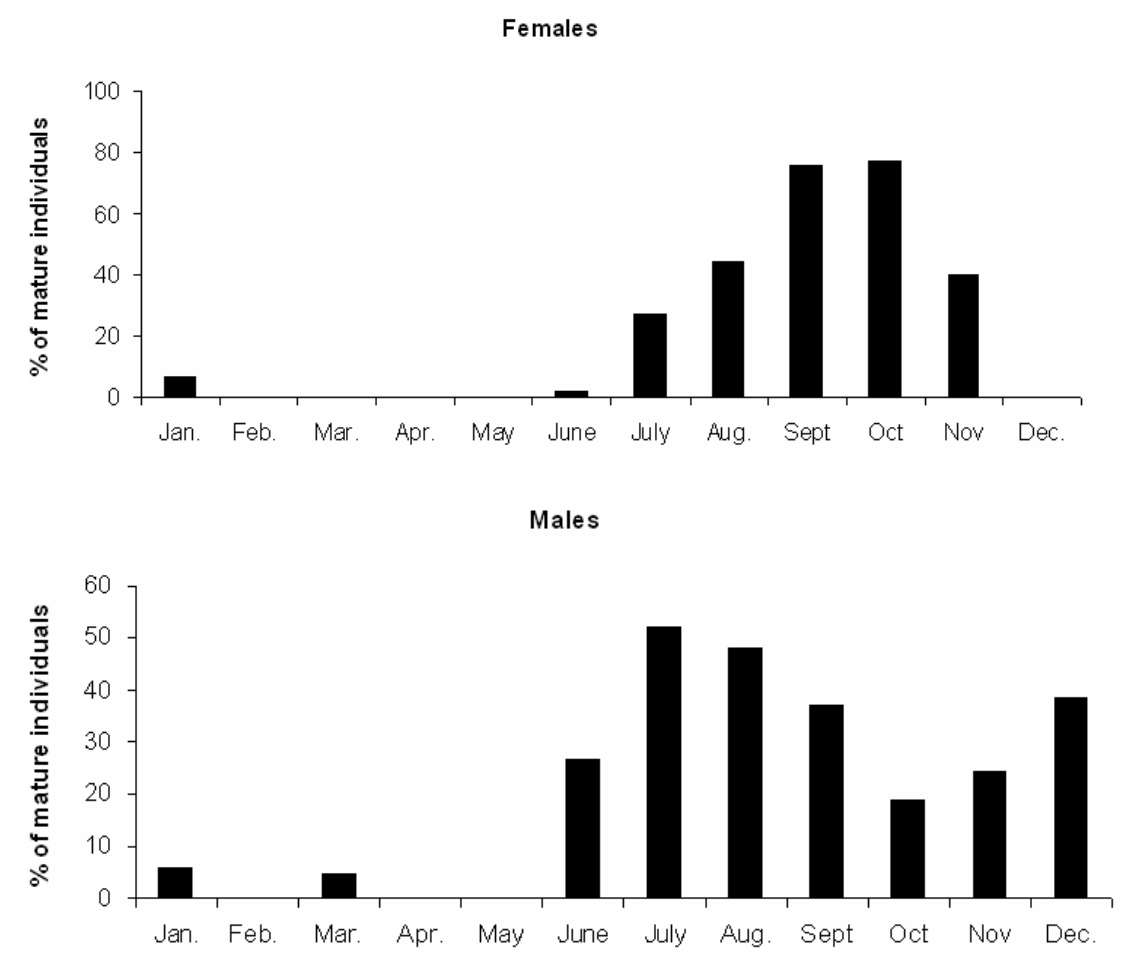

Figure 4 - Mimagoniates microlepis frequency of mature individuals at Ribeirão River during 2002

\section{DISCUSSION}

The tropical regions have little variation of the temperature and photoperiod through the year, still periodic fluctuations of the winds and rains can cause certain seasonality in many tropical ecosystems (Lowe-McConnell, 1999). The fishes can be cyclically affected mainly by the water level changes and by the qualitative and quantitative alterations in the food availability (Bye, 1984; Narahara et al., 1988). According to Vazzoler (1996), the individuals are affected by 
the ambient variables in a way that the conditions at the time of spawning are favorable for the survival and growth of the offspring. Some characteristics are of great importance for the reproductive success, which include the availability of the dissolved oxygen, food availability and risk of the predation (Vazzoler, 1996). Kramer (1978) and Lowe-McConnell (1999) found that a high part of the neotropical fishes reproduced in the rainy season. According to Vazzoler and Menezes (1992), the characids of Amazon basin have its reproductive period directly associated with the pluviosity and at Paraná River basin characins reproductive period is associated with the temperature and pluviosity. In the Brazilian littoral rivers rain regime importance for the reproductive period was recognized in the studies of Menezes and Caramaschi (1994) and Amaral et al. (1998). At Ribeirão river, during the period of the study, it was evident that a seasonal variation in the water level existed, being the winter the time of lesser precipitation with clear reduction of the available environment and the summer the season with highest precipitation and, therefore, increase of the water level and available environment. The torrential rains on the hillsides of nearby mountains during the summer frequently resulted in flash floods. The flash floods can modify the structure of the physical environment and of the fish community, sometimes even changing the course of the river (Aranha et al., 2000).

Data of M. microlepis demonstrated a well defined reproduction period, starting in the winter and ending at the end of the spring. A well defined seasonal reproductive period was also observed in several externally fertilizing characids (Vazzoler and Menezes, 1992) and in another inseminating characid, Diapoma speculiferum (Azevedo et al., 2000). Despite of having a defined reproductive period, there are differences in the time of reproduction activity among the characids. The characids of Amazon basin reproduces during the rainy season and the reproduction period of the characids in the Paraná River basin is related with the increase of the temperature and water level (Vazzoler and Menezes, 1992). No relation with the pluviosity was found for another inseminating species, D. speculiferum, for which the reproductive cycle was correlated with the increase of the day length and temperature (Azevedo et al., 2000).
The insemination of $M$. microlepis seemed to occur in the dry season, when the habitat was reduced and encounters between the males and females were most probable. The offspring development occurred during the rainy months when the habitat increase probably reduced the risk of the predation and increased the availability of the food. According to Nelson (1964), this was one of the main advantages of having internal fecundation; making it possible to separate the events of insemination and spawning.

The length at the first maturation was a flexible reproductive tactic and could present the spatial and temporal variations and also variations within the species (Vazzoler, 1996; Lowe-McConnell, 1999). The males of M. microlepis showed a bigger size than the females at the moment of the first maturation. The males also achieved a bigger size than the females; hence the difference could be a reflex of the sex distinct growth rates. The difference could be also a result of the distinct environmental and biological pressure over the males and females. Further investigation would be necessary to clarify these questions.

The intensity of the reproductive activity index, proposed by Agostinho et al., (1993), allowed an evaluation of the reproductive activity of different portions of the fish populations and it could help to determine the spawning areas. The high values of the IAR for the three sample points demonstrated that the reproductive activity occurred in the whole study area and mainly at the middle portion of the river. Apparently the insemination capacity had a great importance on the reproductive success of $M$. microlepis, allowing it to synchronize the insemination and spawning with the rain regimes and with the most suitable time for the cospecific encounters and offspring survival.

\section{ACKNOWLEDGEMENTS}

We would like to thank S.C. Umbria, S. D. Rosa, J. S. Oliveira, M. A. M. Souza, G. F. Filla, A. P. Barreto for the help. The support by the CNPq is appreciated.

\section{RESUMO}

Exemplares de Mimagoniates microlepis foram coletados entre janeiro e dezembro de 2002. 
Foram escolhidos três pontos amostrais localizados em regiões a montante, média e a jusante do rio Ribeirão no litoral do Paraná. A época reprodutiva foi determinada através da freqüência de estágios de desenvolvimento das gônadas, índice gonadosomático (RGS) e fator de condição gonadal $(\mathrm{K})$. O comprimento médio da primeira maturação $\left(\mathrm{L}_{50}\right)$ e o comprimento médio em que $100 \%$ dos indivíduos são adultos $\left(\mathrm{L}_{100}\right)$ foi calculado. Também foi estimado o índice de atividade reprodutiva (IAR) em cada ponto amostral. $\mathrm{O}$ período reprodutivo teve inicio durante o inverno $\mathrm{e}$ terminou ao final da primavera. Os valores altos do IAR demonstram que a atividade reprodutiva ocorre em toda área estudada e principalmente na porção média do rio. Aparentemente $M$. microlepis sincroniza sua fecundação e desova com o ciclo das chuvas, utilizando os momentos mais adequados para encontros coespecíficos e para sobrevivência dos alevinos.

\section{REFERENCES}

Agostinho, A.A.; Mendes, V.P.; Suzuki, H.I. and Canzi, C. (1993). Avaliação da atividade reprodutiva da comunidade de peixes dos primeiros quilômetros a jusante do reservatório de Itaipu. Rev. Unimar, 15, 175-189.

Amaral, M.F.; Aranha, J.M.R. and Menezes, M.S. (1998). Reproduction of the freshwater catfish Pimelodella pappenheimi in southern Brazil. Stud. Neotrop. Fauna and Environm., 33, 106-110.

Amaral, M.F.; Aranha, J.M.R. and Menezes, M.S. (1999). Age and growth of Pimelodella pappenheimi (Siluriformes, Pimelodidae) from an Atlantic Forest Stream in Southern Brazil. Braz. Arch. Biol. Tech., 42, 449-453.

Aranha, J.M.R. (2000). A influência da instabilidade ambiental na composição e estrutura trófica da ictiofauna de dois rios litorâneos. PhD Thesis, Universidade Federal de São Carlos. São Carlos, Brasil.

Aranha, J.M.R; Gomes, J.H.C. and Fogaça, N.O. (2000). Feeding of two sympatric species of Characidium, $C$. lanei and $C$. pterosticum (Characidiinae) in a coastal stream of Atlantic Forest (Southern Brazil). Braz. Arch. Biol. Tech., 43, 527531.

Azevedo, M.A.; Malabarba, L.R. and Fialho, C.B. (2000). Reproductive biology of the inseminating Glandulocaudine Diapoma speculiferum Cope (Teleostei: Characidae). Copeia, (4), 983-989.
Burns, J.R.; Weitzman, S.H.; Grier, J.H. and Menezes, N. (1995). Internal fertilization, testis and sperm morfhology in Glandulocaudinae fishes (Teleostei: Characidae: Glandulocaudinae). J. Morphol., 224, 131-145.

Bye, V.J. (1984). The role of environmental factors in timing of reproductive cycles, In: Potts, G.W. and Wootton, R.J. Fish Reproduction: Strategies and Tactics. Ed. Academic Press, London, pp. 187 - 202.

Castro, R. M. C. (1999). Evolução da Ictiofauna de Riachos Sulamericanos: padrões gerais e possíveis processos causais. In: Ecologia de peixes de Riachos. Série Oecologia Brasiliensis, Rio de Janeiro, 6, 139155.

Dias, J. F.; Peres-Rios, E. and Chaves, P.T.C. (1998). Análise macroscópica dos ovários de Teleósteos: problemas de classificação e recomendações de procedimentos. Rev. Brasil. Biol., 58, 55-69.

Hartz, S.M.; Vilella, F.S. and Barbieri, G. (1997). Reproduction dynamics of Oligosarcus jenynsii (Characiformes, Characidae) in lake Caconde, Rio Grande do Sul, Brazil. Rev. Brasil. Biol., 57, 295-303.

Isaak-Nahum, V.J. and Vazzoler, A.E.A. de M. (1983). Biologia reprodutiva de Mycropogonias furnieri (Desmarest, 1823) (Teleostei, Scianidae): fator de condição como indicador do período de desova. Bol. Inst. Oceanogr., 32, 63-69.

Köppen, G. W. (1948). Climatologia. Fundo de Cultura Econômica, México, p.478.

Kramer, D.L. (1978). Reproductive seasonality in the fishes of a tropical stream. Ecology, 59, 976-985.

Lampert, V.R.; Azevedo, M.A. and Fialho, C.B. (2003). Hábito alimentar de Mimagoniates microlepis Steindachner, 1876 (Characidae: Glandulocaudinae) do canal de ligação entre as lagoas Emboaba e Emboabinha, Rio Grande do Sul, Brasil. Comum Mus. Ciênc. Tecnol., 16, 3-16.

Lowe-McConnell, R.H. (1999). Estudos ecológicos de comunidades de peixes tropicais. Ed. Edusp, São Paulo, p. 535.

Maack, R. (1981). Geografia física do estado do Paraná. J. Olympio, Rio de Janeiro, 450p.

Mazzoni, R. and Iglesias-Rios, R. (2002). Distribution pattern of two fish species in a coastal stream in southeast Brazil. Braz. J. Biol., 62, 171-178.

Menezes, N.A. (1992). Estudo de caso: sub-família Glandulocaudine (Teleostei: Characiformes, Characidae). In: Situação atual e perspectivas da ictiologia no Brasil. Documentos do IX Encontro Brasileiro de Ictiologia, February 4-8, Maringá, Paraná: Editora da Universidade Estadual de Maringá. p. 39-41.

Menezes, M.S. and Caramaschi, E.P. (1994). Característica reprodutivas de Hypostomus Grupo $H$. punctatus no rio Ubatiba, Maricá, RJ (Osteichthyes, Siluriformes). Rev. Brasil. Biol., 54, 503-513. 
Narahara, M.Y.; Basile-Martins, M.A.; Godinho, H.M. and Cipólli, M.N. (1988). Escala de maturidade, época de reprodução e influência de fatores abióticos sobre o desenvolvimento gonadal de Rhamdia hilarii (Valenciennes, 1840). B. Inst. Pesca, 15, 201-211.

Nelson, K. (1964). Behaviour and morphology in the Glandulocaudinae fishes (Ostariophysi, Characidae). University of California Publications in Zoology, 75, 59-102.

Sabino, J. and Castro, R.M.C. (1990). Alimentação, período de atividade e distribuição espacial dos peixes de um riacho da Floresta Atlântica (Sudeste do Brasil). Rev. Brasil. Biol., 50, 23-36.

Simepar. (2005). Sistema Meteorológico do Paraná. Disponível em: <http://www.simepar.br/> acesso em: 20 set. 2005.

Takeuti, D.F.; Verani, J.R.; Aranha, J.M.R. and Menezes, M.S. (1999). Population structure and condition factor of Pseudotothyris obtusa (Loricariidae, Hypoptopomatinae), from three coastal streams in Southern Brazil. Braz. Arch. Biol. Tech., 42, 397-403.

Vazzoler, A.E.A. de M. (1981). Manual de métodos para estudos biológicos de populações de peixes. Reprodução e crescimento. CNPq, Programa Nacional de Zoologia, Brasília, 108p.

Vazzoler, A.E.A. de M. (1996). Biologia da reprodução de peixes Teleósteos: Teoria e prática. Ed. EDUEM, Maringá, 169p.
Vazzoler, A.E.A. de M. and Menezes, N.A. (1992). Síntese de conhecimentos sobre o comportamento reprodutivo dos Characiformes da América do Sul (Teleostei, Ostariophysi). Rev. Brasil. Biol. 52 (4): 627-640.

Weitzman, S.H.; Menezes, N.A. and Weitzman, M.J. (1988). Phylogenetic biogeography of the Glandulocaudini (Teleostei, Characiformes, Characidae) with coments on the distribution of freshwater fishes in Eastern and Southeastern Brazil. In: Workshop on neotropical distribution patterns. Acad. Brasileira de Ciências, Rio de Janeiro, p. 379427.

Weitzman, S.H.; Menezes, N.A.; Evers, H-G. and Burns, J.R. (2005). Putative relationships among inseminating and externally fertilizing characids, with a description of a new genus and species of Brazilian inseminating fish bearing an anal-fin gland in males (Characiformes: Characidae). Neotropical Ichthyology, 3 (3):329-360.
Received: March 13, 2006; Revised: June 28, 2006; Accepted: March 13, 2008. 